2019-01-02

\title{
Spaces of Tolerance: Editorial
}

\section{Introduction}

\author{
Troiani, I
}

http://hdl.handle.net/10026.1/16411

10.1080/20507828.2019.1583967

Architecture and Culture

All content in PEARL is protected by copyright law. Author manuscripts are made available in accordance with publisher policies. Please cite only the published version using the details provided on the item record or document. In the absence of an open licence (e.g. Creative Commons), permissions for further reuse of content should be sought from the publisher or author. 


\title{
Architecture and Culture
}

\section{Spaces of Tolerance: Editorial Introduction}

\author{
Igea Troiani \& Suzanne Ewing
}

To cite this article: Igea Troiani \& Suzanne Ewing (2019) Spaces of Tolerance: Editorial Introduction, Architecture and Culture, 7:1, 7-12, DOI: 10.1080/20507828.2019.1583967

To link to this article: https://doi.org/10.1080/20507828.2019.1583967

$$
\text { 曲 Published online: } 01 \text { Jul } 2019 .
$$

Submit your article to this journal $\sqsubset$

\section{Џ Article views: 57}

Q View related articles $₫$

View Crossmark data ¿ 


\section{ARCHITECTURE ANO CULTURE}

Igea Troiani

Department of Architecture, Xi'an Jiaotong-Liverpool University, Suzhou, China Igea.Troiani@xjtlu.edu.cn

\section{Suzanne Ewing}

Edinburgh School of

Architecture and Landscape Architecture, The University of Edinburgh, Edinburgh, UK Suzanne.ewing@ed.ac.uk

Volume $7 /$ Issue 1

March 2019

pp.7-12

DOI:10.1080/20507828.

2019.1583967

No potential conflict of interest was reported by the authors.

(C) 2019 Informa UK Limited, trading as Taylor \& Francis Group

\section{Spaces of Tolerance: Editorial Introduction}

\section{Igea Troiani and Suzanne Ewing}

Architecture and Culture is published in both print and online formats. However you are reading or viewing this, whether as the beginning of an unfolding hardcopy or as a browsed or searched internet interlude, we offer this short editorial introduction to the issue entitled "Spaces of Tolerance" to set out its scope of content. Rather than following conventional editorial protocol of summarizing each article included in the issue, we instead invite you to be attentive to your multi-sensorial experience as a reader/viewer, to practices of reading, looking and listening. Feel free to read the longer abstract provided for each article, download the interactive PDF, watch the films referred to in the relevant articles and enjoy the audiovisual while you read the written prose. Immerse yourself in the broader sensorial page/screen of architectural publishing where work can undergo continuous re-reading and reevaluation, moving backwards and forwards in different ways and at various speeds. Expansion of knowledge and scholarship in these hybrid spaces of academic publication is material and experiential but is always partial in some way. ${ }^{1}$

Established in 2013, Architecture and Culture accommodates conventional and unconventional submissions to expand our understanding of what merits interdisciplinary and architectural publication. The journal is directed at multidisciplinary practitioners and 
audiences of researchers and scholars including, but not limited to, architects, artists and urban designers, filmmakers, animators and poets, historians, geographers, anthropologists and other social scientists. As architecturally trained writers broaden their knowledge of and modes of practice learned from other disciplines, and non-architecturally trained writers expand their and our knowledge of architecture, it has become possible to consider what is valuable to publish in architecture, and also how it is read, viewed and received. This position builds on the writings of feminist thinkers such as Donna Haraway and Elizabeth Grosz, exploring knowledge exchange within and beyond academic institutions and "the particularity and embodiment of all vision."

Grosz presents the potential for a space for open interdisciplinary research and practice exchange. The celebration of difference - a second-wave feminist and postmodern agenda; the emergence of new terms and languages; transformations of tired disciplinary practices and tactics; and a questioning of the value of subjective and practice-based research - has created a broader space of architectural publishing tolerance. Grosz argues that "to be outside [something] is to afford oneself the possibility of a perspective [...]."3 "A third space in which to interact without hierarchy, a space or position outside both, a place that doesn't" yet exist ${ }^{4}$ is detached from the mainstreams of both disciplines and is located at the peripheries or boundaries of each, where tolerances lie. A "third space" can exist in a designer's practice, the space of the author's writing, in the peer reviewer or editor's review, and even in the reader's sensorial cognition and embodied gaze.

Since establishing the journal we, along with our co-editors Diana Periton and Jessica Kelly, reviews editor Stephen Walker and guest editors, have sought to open up what is published in between architecture and other disciplines. This issue of "Spaces of Tolerance" aims to intensify reflection on the blurry space inside and outside acceptable academic publication more explicitly than earlier issues. It is provoked by the increasingly intolerant academic climate (politically and socially) in which can find ourselves today.

In an effort to recover architectural publishing as a more liberal, designerly, yet rigorous, space of production and imagination and to present critical socio-political positions, this issue reveals nuances in publishing and associated academic practices that might exceed or distil conventional and accepted disciplinary limitations. It seeks to instigate more open-ended relationships, interpretations and iterations between theory and practice - between textuality, visuality and aurality - to sway between and across arts and humanities disciplines with empathy and insight. In light of our agenda to accommodate class, cultural, artistic and gender difference, articles in this issue present varied cultural and geographical positions and perspectives that examine aspects of the discourse, practice and research of architecture as an exploration of 
"Spaces of Tolerance." Further, we hope that we have enabled some productive (minor) disciplinary maneuvering.

Our call for contributions invited discourse on: disciplinary tolerances and constraints - environmental, cultural, aesthetic and philosophical; ${ }^{5}$ spatial and temporal tolerance in the architectural project as research inquiry or conceptual field; and physical and digital tolerances - in material assemblages, production, and between drawing and building, purity and impurity. ${ }^{6}$ We oriented tolerant practices and zero tolerance as having material, spatial and cultural dimensions, with capacity and agency of terms of reference such as instruction, specification, revision, refinement, feedback, approval, completion. Social, cultural and political tolerance and threats include control of information, image, author, reader; evidenced in extremities, margins and marginality; and acceptable levels of deviation, divergence, variation, imprecision. Contributions in this issue have been motivated to actively examine our collective editorial processes, which aim to engender a space of positive collaboration that selects with a critical generosity, respects "voice" and fine tunes authors' submissions to the highest level of quality and readability through a process of "becoming" a publication.

In order to create tolerant space in architectural publication, Justine Clark and Paul Walker consider "processes of 'interpretation,' rather than 'judgement'" and suggest that critics and reviewers engage in "a more complex understanding of the role of "intention of the work.". If the "intention of the work" is to present unlikely exchanges and to argue positions between architecture and an/other discipline(s) or to explore audio, audiovisual or hypermedia as a form of communication, then the work needs to be understood as "'a way of making,' even of worldmaking" " delivered in "a productive and creative practice."9 Submissions are peer reviewed as a project of interpretation and imagination. ${ }^{10}$ This is explored further in our article entitled "Tolerance in the Peer Review of Interdisciplinary Research," which exposes explicit interplay between contingent context and autonomous production needed in the academic peer review process when confronted by interdisciplinary scholarship, or work that may not "fit" or be "tolerated" in mainstream academic publishing. But what is publishable has been complicated even further because of the neoliberalization of academic research and its associated publishing infrastructures.

Being dragged along by the model of publishing in the sciences, academic journal publishing worldwide has become increasingly watched over and policed by funding bodies and institutions demanding that scholarship be seen to have direct and maximized impact for economic gain or return. As Wendy Brown notes, "the move to judge every academic endeavour by its uptake in non-academic venues (commerce, state agencies, NGOs [nongovernmental organizations]), as the UK Research Excellence Framework (REF) does, is [... ] damaging" because "academic 
practices have been transformed by neoliberal economization."11 This monitoring, counting, measuring and quantifying frames assessment of the validity of architectural research and limits the exchange between architectural practice, publishing and creative research. Within academic institutions disciplines create boundary conditions of more or less tolerance in judging the value of architectural outputs and the limits of the form and formats that original and creative research can appear.

Rather than read this moment in architectural scholarship as a crisis of critical production, we argue that tolerance in interdisciplinary research in architecture offers a sensorial enrichment and essential augmentation to architectural knowledge. In Architecture and Culture, the professional/artistic academic/researcher opens up their work to readers and viewers of differing levels and appearances of scholarship to cultivate diverse and productive conversations "between speakers, listeners, givers and receivers" for "an open and vast space with room enough for all kinds of manoeuvring." 12 This first issue of the seventh volume of Architecture and Culture consciously includes visual provocations and articles by Jane Smitheram, Ebba Hogstrom and Gesa Helms, Ektoras Arkomanis, Corinna Dean, Duarte Santos and Victoria Watson. Visual - drawn, photographic and filmic - evidence constructed by authors is core to the research of a number of other articles by Julieanna Preston, Bart Decroos and Lara Schrijver, Zeljka Pjesivac, Aleksandar Stanicic and Milan Sijakovic, Sayan Skandarajah, Dane Clark and Aaron Tobey.

Raising questions of tolerance has exposed issues of control, containment, breaking points and appropriate tools and techniques. How much a material or spatial condition's interior limits become a refuge, or alternatively are constrained and intolerant, is explored through different approaches taken by the contributions of Preston, Hogstrom and Helms, Decroos and Schrijver, Pjesivac and Dean, Santos and Watson. Social and temporal dimensions of control and tolerance, and the urban exterior as a site for social, material tolerances and adjustments, are demonstrated in the articles by Arkomanis, and Stanicic and Sijakovic. From urban islands or solidified remnants, to camps and spaces in between: tolerance is concerned with a physical and conceptual space or gap, varied certainties, negotiations and re-writings of the definitions of edges. Tools of tolerance may move between established architectural knowledge and new technologies, as considered in Skandarajah's work on drawing practices that traverse Eastern and Western traditions, reflecting on historical representations of urban Tokyo, Japan. Clark and Tobey's article exposes aspects of the forward trajectory of contemporary digitalmaterial representational architecture being built in Brooklyn, USA. Smitheram's frontispiece and endpiece are graphical slogan provocations that use techniques of color inversion over torn fragments of the complex seen/unseen spatial choreographies of nineteenth-century "architectural" interiors. In this issue we aim to provoke and extend the academic 

publication.

Igea Troiani (PhD) is an architect, academic and independent filmmaker who has worked in Australia, Germany, the UK and China. She is currently a Professor of Architecture at Xi-an Jiaotong-Liverpool University in Suzhou. Her portfolio of research is based in three areas: (1) the social production of architecture; (2) architecture, neoliberalism and labor; and (3) architecture and media. In addition to her written publications, she produces theory as film; since 2004, she has made films on the politics of architectural production, most recently under her production company Caryatid Films. She is a founder of Original Field of Architecture (Oxford, UK) with Andrew Dawson and founder and editor-in-chief of the interdisciplinary, award-winning journal Architecture and Culture.

Suzanne Ewing is an architect, academic and educator and was Head of the Edinburgh School of Architecture and Landscape Architecture at the University of Edinburgh, 2016-18. She co-founded ZONE architects, UK, in 2002. Underpinning the inquiry of her critical design work in sited architecture projects and the speculative domain of design studios in education, is elucidating and nuancing theories, skills, judgments and potentials embedded in practice-based methodologies, which traverse aesthetics and ethics: knowing how to practice, knowing how to construct a good project. Publications include Architecture and Field/Work (Routledge, 2011), and articles in Journal of Architecture, Architectural Theory Review, NORDIC and Charette. She is co-editor of the international award-winning journal Architecture and Culture.

\section{Notes}

1 Donna Haraway, "Situated Knowledges: The Science Question in Feminism and the Privilege of Partial Perspective," Feminist Studies, 14, no. 3 (1988), 575-599.

2 Ibid., 582.

3 Elizabeth Grosz, Architecture from the Outside: Essays on Virtual and Real Space (Cambridge, MA: MIT Press, 2001), xv.

4 Ibid., xvii.

5 Josh Taron, "Critical Tolerance," OffRamp, 12, Fall/Winter 2016.

6 Muf architecture/art, Public Views 1: Purity and Tolerance. London: Architecture Foundation, installation 7-17 September 1995, available online: http://muf.co.uk/ portfolio/purity-and-tolerance/ (accessed March 27, 2019)

7 Justine Clark and Paul Walker, "Negotiating the Intention of the Work," Volume, special issue "Ways to Be Critical," 36 (2013): 25.

8 David Leatherbarrow, "The Craft of Criticism," Journal of Architectural Education, 62, no. 3 (2009): 21.

9 Naomi Stead, "Three Complaints about Architectural Criticism," Architecture Australia, 92, no. 6 (2003), 50.

10 Leatherbarrow, "Craft of Criticism," 96-97; Joseph Rykwert, “Does 
Architecture Criticism Matter?," Domus, no. 979 (April 2014): 4.

11 Wendy Brown, "Educating Human Capital," in Undoing the Demos: Neoliberalism's Stealth Revolution (Cambridge, MA: MIT Press), 196.
12 Kristina Lee Podevsa, "Between the Question Mark and the Comma," FillipFolio A, available online: https://fillip.ca/ content/between-the-question-markand-the-comma (accessed February 3, 2019).
12

Spaces of Tolerance: Editorial Introduction Igea Troiani and Suzanne Ewing

\section{References}

- Brown, Wendy. 2015. "Educating Human Capital." In Undoing the Demos: Neoliberalism's Stealth Revolution, 175-200. Cambridge, MA: MIT Press.

- Clark, Justine, and Walker, Paul. 2013. "Negotiating the Intention of the Work," Volume, 36 [special issue "Ways to Be Critical"]: 24-29

- Grosz, Elizabeth. 2001. Architecture from the Outside: Essays on Virtual and Real Space. Cambridge, MA: MIT Press.

- Haraway, Donna. 1988. "Situated Knowledges: The Science Question in Feminism and the Privilege of Partial Perspective." Feminist Studies, 14, no. 3: 575-599.

- Leatherbarrow, David. 2009. "The Craft of Criticism." Journal of Architectural Education 62, no. 3: 20-99.

- Muf architecture/art. n.d., Public Views 1: Purity and Tolerance. London. Architecture
Foundation, installation 7-17 September 1995. Available online: http://muf.co.uk/ portfolio/purity-and-tolerance/ (accessed March 27, 2019).

- Podevsa, Kirstina L. 2010. "Between the Question Mark and the Comma." FillipFolio A. Available online: https://fillip.ca/ content/between-the-question-markandthe-comma (accessed February 3, 2019).

- Rykwert, Joseph. 2014. "Does Architecture Criticism Matter?" Domus, no. 979, April: 2-5.

- Stead, Naomi. 2003. "Three Complaints about Architectural Criticism.” Architecture Australia, 92, no. 6: 50-52.

- Taron, Josh. 2016. "Critical Tolerance." OffRamp, 12, Fall/Winter. Available online: https://offramp.sciarc.edu/articles/criticaltolerance (accessed March 27, 2019). 